九州大学学術情報リポジトリ

Kyushu University Institutional Repository

\title{
Characterization of Coleosporium phellodendri Causing Rust Disease on Japanese Prickly-ash Tree
}

Back, Chang-Gi

Division of Applied Biology and Chemistry, College of Agriculture and Life Sciences, Kyungpook National University

Nam, Gu-Youn

Division of Applied Biology and Chemistry, College of Agriculture and Life Sciences, Kyungpook National University

Kyu Kyu Win, Nang

Division of Applied Biology and Chemistry, College of Agriculture and Life Sciences, Kyungpook National University

Lee, Seung-Yeol

Division of Applied Biology and Chemistry, College of Agriculture and Life Sciences, Kyungpook National University

他

https://doi.org/10.5109/25194

出版情報：九州大学大学院農学研究院紀要. 57 (2)，pp. 379-382，2012-09-20. Faculty of Agriculture, Kyushu University

バージョン：

権利関係 : 


\title{
Characterization of Coleosporium phellodendri Causing Rust Disease on Japanese Prickly-ash Tree
}

\author{
Chang-Gi BACK ${ }^{1}$, Gu-Youn NAM ${ }^{1}$, Nang KYU KYU WIN ${ }^{1}$, Seung-Yeol LEE ${ }^{1}$, \\ In-Kyu KANG ${ }^{1}$, Sang-Chul LEE ${ }^{1}$, Hee-Young JUNG ${ }^{1 *}$ and Shoji OHGA*
}

\author{
Laboratory of Forest Resources Management, Division of Agro-environmental Sciences, \\ Department of Forest Environmental Sciences, Faculty of Agriculture, \\ Kyushu University, Sasaguri, Fukuoka 811-2415, Japan \\ (Received April 4, 2012 and accepted May 10, 2012)
}

\begin{abstract}
A typical rust symptom showing yellowish spots on upper surface and pustules on lower surface of leaves was observed on Japanese prickly-ash tree (Zanthoxylum ailanthoides) in Hyeonpo-ri, Bukmyeon, Ulleungdo, Korea in 2010. Based on the morphological characteristic of urediospores and teliospores, the rust fungus was identified as Coleosporium phellodendri. The urediospores were yellowish in color, globose in shape with annulated verrucae surface and $26 \sim 37 \times 22 \sim 28 \mu \mathrm{m}$ in size. The teliospores were reddish yellow, ellipsoid and 43 63×23 33 $\mathrm{m}$ in size. Phylogenetic analysis of the 28S rDNA region sequences of this fungus supported that it belong to Coleosporium spp.. This is first record of $C$. phellodendri causing rust disease on Japanese prickly-ash tree in Korea.
\end{abstract}

Keywords: Coleosporium phellodendri, Japanese prickly-ash tree, rust disease, Zanthoxylum ailanthoides

\section{INTRODUCTION}

Rust fungi which are obligate parasites are one of the notorious pathogens which cause considerable losses of several crops including valuable crops and weeds in the world (Barnes and Szabo, 2007; Kurose et al., 2009). In Korea, rust diseases have been recorded from several plant species including prickly-ash (Zanthoxylum schinifolium), hawthorn (Crataegus sp.), garlic (Allium fistulosum), white false hellebore (Veratrum patulum), etc. and the rust fungi were Coleosporium neocacaliae, Gymnosporangium globosum, Puccini alli, Uromyces veratri, etc. (Lee et al., 2003; Kim and Lee, 2005; Lee et al., 2008; Yun et al., 2008). Especially in Ulleungdo, more than 35 species of rust have been recorded (Lee et al., 1997). In 2010, rust symptoms were occurred on Japanese prickly-ash tree (Zanthoxylum ailanthoides) belongs to family Rutaceae in Ulleungdo, Korea. The tree is distributed in China, Japan, Philippines, Taiwan, and South Korea. Its stems and leaves are used as folk medicine for rheumatism, arthritis and common cold in China and Taiwan (Cheng et al., 2005; Chung et al., 2006). So far, rust disease on Japanese prickly-ash tree has not been reported in Korea. Therefore, the causal rust fungus was studied on the basis of morphological characteristics spores and the 28S rDNA gene sequence analysis. Seasonal rust disease development on Japanese pricklyash trees was also observed.

\footnotetext{
Division of Applied Biology and Chemistry, College of Agriculture and Life Sciences, Kyungpook National University, Daegu 702-701 Korea

* Corresponding authors (E-mail: ohga@forest.kyushu-u.ac.jp, heeyoung@knu.ac.kr)
}

\section{MATERIALS AND METHODS}

\section{Morphological characteristics}

Seasonal rust disease development on Japanese prickly-ash trees was assessed from June to October 2010 in Ulleungdo, Korea. Fresh leaves showing rust symptoms were collected from Ulleung-gun Agriculture Technology center in Hyeonpo-ri, Buk-myeon, Ulleungdo. Morphological characteristics of uredinia and urediniospores were observed by light microscope ((IX 51, Olympus Inc., USA). The surface structure of the uredinia and urediniospores were also investigated by scanning electron microscope (SEM). For SEM observation, the samples were coated with platinum-palladium by a Hitachi E-1030 platinum ion coater and then observed under a Hitachi S-4300 scanning electron microscope (Hitachi, Tokyo, Japan). The morphological characters of the fungus were compared to the previous descriptions of the rust fungi (Hiratsuka, 1992).

\section{DNA extraction and PCR amplification}

Total genomic DNAs were extracted separately from urediniospores and teliospores of the infected leaves as previously described procedure (Liu et al., 2000). Using a sterile toothpick, the spores were taken from the leaf's surface and transferred to a $1.5 \mathrm{ml}$ tube containing $400 \mu \mathrm{l}$ of lysis buffer (400 mM Tris-HCl [pH 8.0], 60 mM EDTA [pH 8.0], $150 \mathrm{mM} \mathrm{NaCl}, 1 \%$ sodium dodecyl sulfate). The extraction procedure was done under room temperature and centrifugation was $10,000 \times g$. After disruption of the spores, the tube was left for $10 \mathrm{~min}$. The $3 \mathrm{M}$ sodium acetate $(150 \mu \mathrm{l}), \mathrm{pH} 5.2$ was added to the tube and vortexed it briefly. After centrifugation for $2 \mathrm{~min}$, the supernatant was transferred to new $1.5 \mathrm{ml}$ tube and added equal volume of isopropyl alcohol. The tube was mixed by briefly inversion and centrifuged for 2 min and the supernatant was discarded. The resultant DNA pellet was 
washed with $300 \mu \mathrm{l}$ of $70 \%$ ethanol and centrifuged for 3 min. The DNA pellet was air dried and dissolved in $50 \mu \mathrm{l}$ of sterilized distilled water. The total genomic DNA was frozen at $-20^{\circ} \mathrm{C}$ and used as template DNA for PCR.

The total genomic DNA was used to amplify the partial 28S rDNA of ribosomal DNAs. The $28 \mathrm{~S}$ rDNA region was amplified with the primer pairs of D1 (5'-ACC CGC TGA AYT TAA GCA TAT-3')/ D2 (5'-CTC CTT GGT CCG TGT TTC AAG ACG G-3') (Auwera et al., 1994). PCR amplification was performed in $20 \mu \mathrm{l}$ of the reaction mixture containing 20 ng of fungal genomic DNA, 5 unit of Taq polymerase (Solgent, Daejeon, Korea), $2 \mu \mathrm{l} 10 \mathrm{X}$ reaction buffer (100 mM Tris- $\mathrm{HCl}, 400 \mathrm{mM} \mathrm{KCl,} 15 \mathrm{mM}$ $\mathrm{MgCl}_{2}, \mathrm{pH} 9.0$ ), $10 \mathrm{mM}$ dNTPs mixture and $5 \mathrm{pmol}$ of each primer using Applied Biosystems 2720 thermal cycler. The PCR conditions were $94^{\circ} \mathrm{C}$ for $3 \mathrm{~min} ; 35$ cycles of $94^{\circ} \mathrm{C}$ for $30 \mathrm{~s}, 52^{\circ} \mathrm{C}$ for $30 \mathrm{~s}, 72^{\circ} \mathrm{C}$ for $1 \mathrm{~min}$; and $72^{\circ} \mathrm{C}$ for $7 \mathrm{~min}$ for the final extension. The resultant DNA fragments were purified using ExoSAP-IT (GE Healthcare,
Buckinghamshire, UK) and directly sequenced with the same primers.

\section{Phylogenetic analysis}

The obtained sequence was aligned using DNASTAR computer package (DNASTAR Inc.) and compared with the 28S rDNA sequences of other Coleosporium sp. retrieved from GenBank database. The phylogenetic tree was constructed using the neighbor-joining method in the CLUSTAL W. Bootstrap analysis with 100 replications was performed to determine support for various clades. The sequence was deposited at GenBank database.

\section{RESULTS AND DISCUSSION}

Seasonal rust disease development was observed on Japanese prickly-ash tree (Z. ailanthoides) during June to October 2010. The initial rust symptoms started on

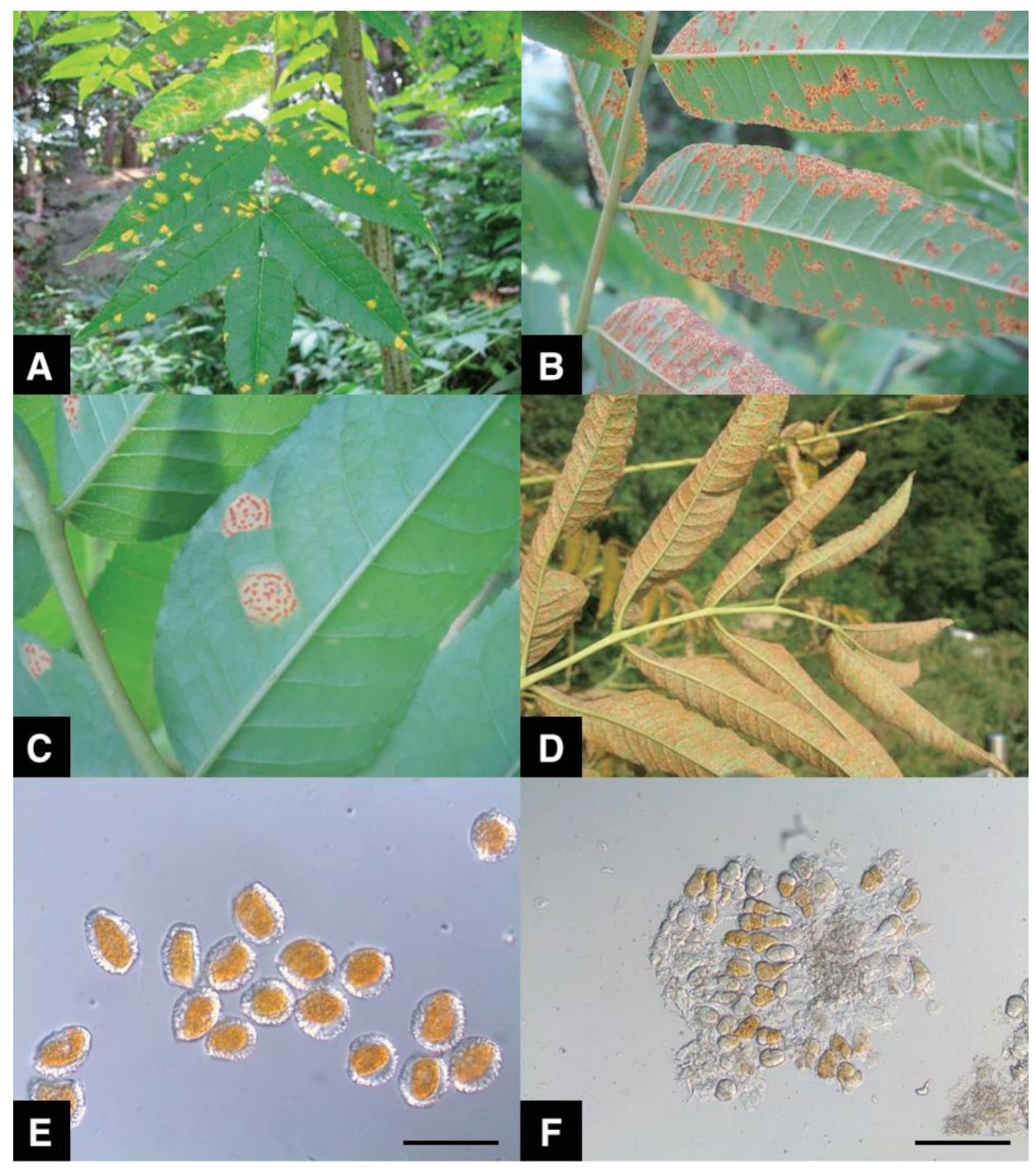

Fig. 1. Rust symptoms on Japanese prickly-ash leaves and morphological characters of urediniospores and teliospores; yellow spots on upper side of leaves in June (A); uredinia on underside of leaves in July (B); telia on the underside of leaves in August (C); severely infected leaves in September (D); yellowish globose-shaped urediniospores (E) (scale bar=50 $\mu \mathrm{m}$ ); reddish ellipsoid-shaped teliospores $(\mathrm{F})$ (scale bar=50 $\mu \mathrm{m}$ ). 
early June with 2 or 3 tiny yellowish spot on upper side of the leaves. The yellowish spots became rounded and enlarged in size of $2 \sim 4 \mathrm{~mm}$. The uredinia formed on under side of the leaves in early July. Later, the uredinia fused together and formed typical rust symptoms that turned browning the tissues around uredinia (Fig. 1A). Some uredinia ruptured and exposed the urediniospores that can be visible as yellowish spore masses. After the raining season, the whole leaves were covered with urediniospores. Severe rust symptoms were observed as orange colored spots on affected leaves (Fig. 1B). In August, telia of reddish-yellow projection formed on underside of leaves (Fig. 1C) and the uredinia also existed on the same leaves. The severely infected leaves dried and defoliated in September (Fig. 1D). The infected leaves were observed on the trees until leaf falling period of October.

By light microscopic examination, uredinial and telial stages were observed on leaves of Japanese pricklyash tree. Urediniospores were orange globose, subglobose or broad-ellipsoid and $26 \sim 37 \times 22 \sim 28 \mu \mathrm{m}$ in size (Fig. $1 \mathrm{E}$ and Fig. 2A and $2 \mathrm{~B}$ ). The surface of urediniospores were columnar verrucae (Fig. 2C) and the verrucae were 2.1 2.5 $\mu \mathrm{m}$ high and $0.6 \sim 0.9 \mu \mathrm{m}$ wide (Fig. 2D). Teliospores were reddish-orange, one-celled, oblong ellipsoid, one-layered crusts with $43 \sim 63 \times 23 \sim 33 \mu \mathrm{m}$ in size (Fig. 1F). The morphological characteristics of the urediniospores and teliospores, the rust fungus is similar to those descriptions of Coleosporium phellodendri (Hiratsuka, 1992). The comparison of morphological characteristic between the isolate in this study and previous described $C$. phellodendri were presented in Table 1. Therefore, by the morphological characteristics, the fungus was identified as C. phellodendri although their sizes in the present study were somewhat bigger than the previous described isolate.

The 28S rDNA gene sequences of urediospores and teliospores were $100 \%$ homology with each other. One sequence of the fungus was deposited in the DDBJ/ GenBank database (AB639023). The 28S rDNA gene sequence of the fungus revealed that it was $98.6 \%$ homology with those of Coleosporium campanulae (AF426244), C. cacaliae (AF426243) and C. senecionis (AY512840). The phylogenetic tree showed that the rust

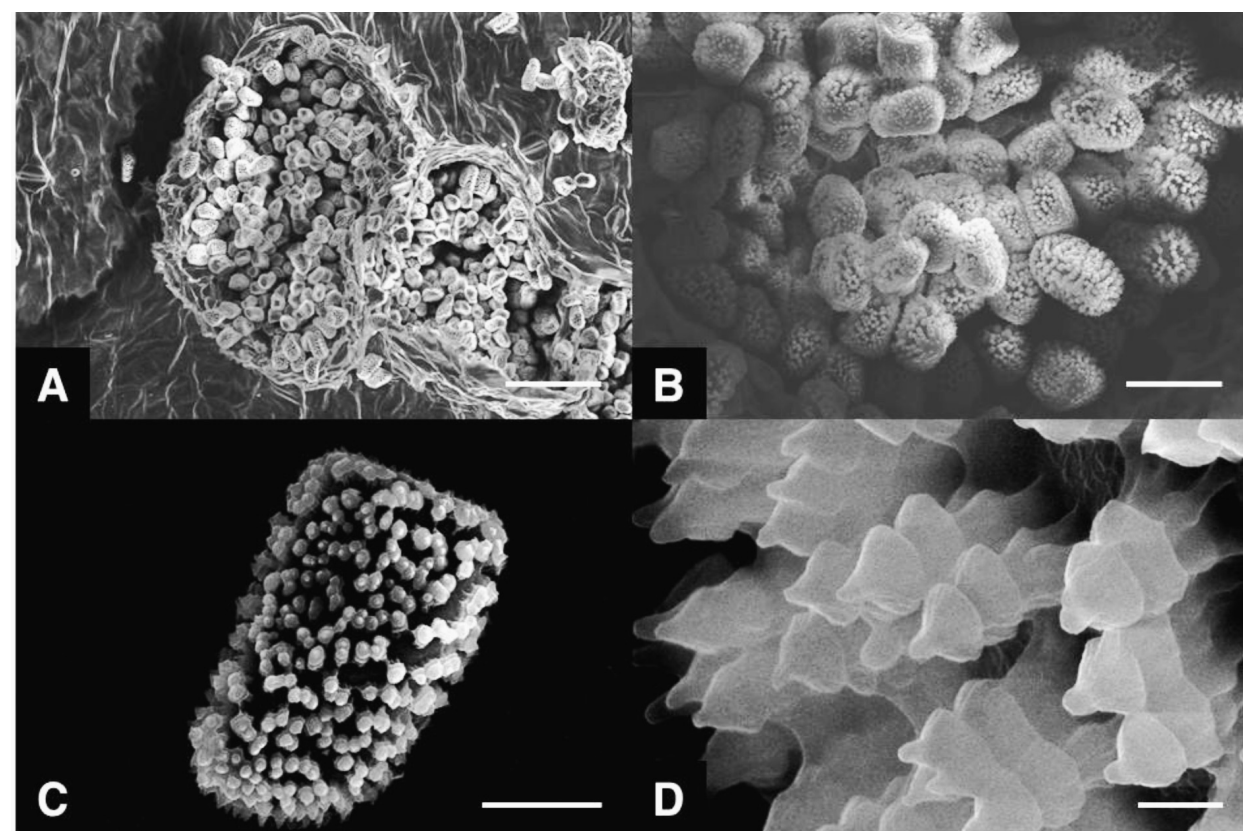

Fig. 2. Scanning electron micrographs of uredinia and urediniospores of C. phellodendri; uredia (scale bar $=100 \mu \mathrm{m})(\mathrm{A})$; close up view of uredia (scale bar=25 $\mu \mathrm{m})(\mathrm{B})$; verrucae of an urediniospore (36 to 41 per $10 \mu \mathrm{m}$ square, scale bar=10 $\mathrm{m}$ ) (C); sinuate and mucronate apex of annulate verrucae (scale bar $=1 \mu \mathrm{m}$ ) (D).

Table 1. Comparison of morphological features of the present isolate with Coleosporium phellodendri described by Hiratsuka (1992)

\begin{tabular}{llll}
\hline Characteristics & & Present isolate & C. phellodendri \\
\hline Urediniospores & Color & yellow & yellow \\
& Shape & globose, subglobose, ellipsoid, verrucae & globose, subglobose or broad-ellipsoid, verrucae \\
& Size & $27-36 \times 25-28 \mu \mathrm{m}$ & $20-36 \times 16-30 \mu \mathrm{m}$ \\
\hline \multirow{2}{*}{ Teliospores } & Color & reddish-yellow or orange & reddish-yellow or orange \\
& Shape & one-celled, cylindrical, ellipsoid & one-celled, cylindrical, obovate or ellipsoid \\
& Size & $43-63 \times 23-30 \mu \mathrm{m}$ & $40-85 \times 21-29 \mu \mathrm{m}$ \\
\hline
\end{tabular}




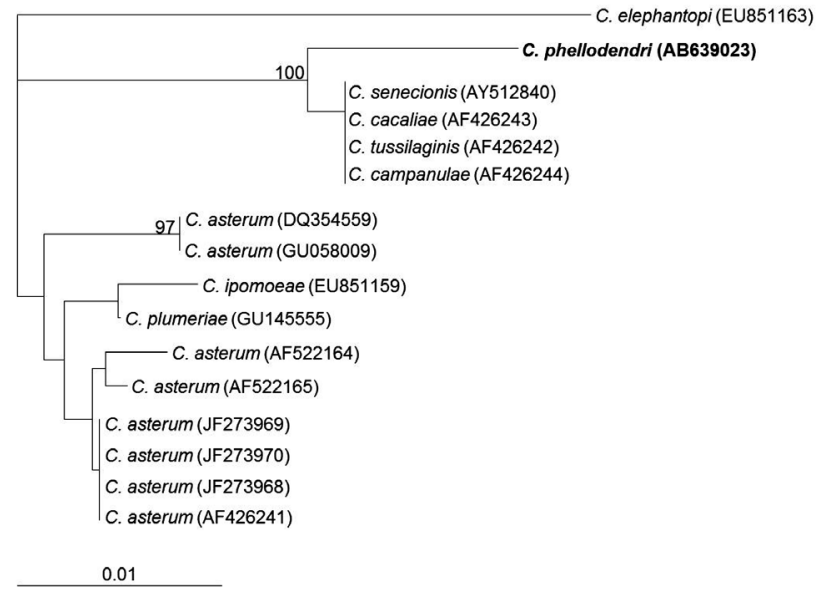

Fig. 3. Phylogenetic trees constructed by the neighbor-joining method, comparing the partial of 28S rDNA sequences of Coleosporium phellodendri with those of other Coleosporium species from GenBank. C. elephantopi (EU851163) was used as the outgroup. Numbers on branches are confidence values obtained for 100 replicates (only values above $80 \%$ are shown). The bar represents a phylogenetic distance of $1 \%$.

fungus from Japanese prickly-ash tree was closely related to C. campanulae, C. cacaliae, C. senecionis and $C$. tussilaginis (Fig. 3). Based on phylogenetic analysis, the rust fungus occurred on Japanese prickly-ash tree was confirmed that it belongs to Coleosporium spp..

In Korea, Coleosporium phellodendri has been recorded as one of the pathogens causing seven pine rust diseases in 1940 but the morphological characters of this fungus were not mentioned. Its middle hosts are amur cork tree (Phellodendron amurense) and sakhalin cork tree ( $P$. sachalinense) which belong Rutaceae (The Korean Society of Plant Pathology, 2009). Since Japanese prickly-ash tree ( $Z$. ailanthoides) is also belonged to Rutaceae, this tree might be a middle host for $C$. phellodendri. In Ulleungdo, 5 species of Coleosporium sp. had been identified including $C$. asterum, C. cldmatidis, C. clerodendri, C.horianum and C. plectranthi (Kim, 2001). The C. phellodendri has not been identified and reported before from Japanese prickly-ash trees (Z. ailanthoides). This is the first observation of mor- phological characteristic of $C$. phellodendri and also the first occurrence $C$. phellodendri infection on Japanese prickly-ash trees in Korea.

\section{REFERENCES}

Auwera, G. V., S. Chapelle and R. D. Wachter 1994 Structure of the large ribosomal subunit RNA of Phytophthora megasperma, and phylogeny of the oomycetes. FEBS Letters, 338 : $133-136$

Barnes, C. W. and L. J. Szabo 2007 Detection and identification of four common rust pathogens of cereals and grasses using real-time polymerase chain reaction. Phytopathology 97: $717-727$

Cheng, M. J., K. H. Lee, I. L. Tsai and I. S. Chen 2005 Two new sesquiterpenoids and anti-HIV principles from the root bark of Zanthoxylum ailanthoides. Bioorg. Med. Chem., 13: $5915-5920$

Chung, Y. C., C. T. Chien, K. Y. Teng and S. T. Chou 2006 Antioxidative and mutagenic properties of Zanthoxylum ailanthoides Sieb \& zucc. Food Chem., 97: 418-425

Hiratsuka, N., S. Sato, K. Datsuya, M. Kakishima, Y. Hiratsuka, S. Kaneko, Y. Ono, T. Sato, Y. Harada, T. Hiratsuka and K. Nakayama 1992 The rust flora of Japan. Tsukuba Shuppankai, Takezono, Ibaraki, p. 232

Kim, S-H. 2001 Taxonomic study of rust fungi (Uredinales) in Korea. Incheon: University of Incheon

Kim, S-H. and T-S. Lee 2005 Rust of Veratrum patulum caused by Uromyces veratri. Korean J. Mycol., 33: 95-97

Kurose, D., N. Furuya, M. Matsumoto, D. H. Djeddour, H. C. Evans and K. Tsuchiya 2009 Identification of an aecidial rust on Fallopia japonica. J. Fac. Agr., Kyushu Univ., 54: 53-57

Lee, D-H., J-S. Hur and Y. J. Koh 2003 Occurrence of garlic rust in Southern regions of Korea. Res. Plant Dis. 9: 121124

Lee, S. K., D. W. Kim, Y. S. Moon and J. J. Kim 2008 A new needle rust fungus Coleosporium neocacaliae on the needles of pinus Korea. Res. Plant Dis., 14: 214-218

Lee, T. S., M. W. Lee and H. D. Shin 1997 Rust fungi collected from Ulleung island in Korea. Korean Soc. Mycol., News Letter, 9: 24

Liu, D., S. Coloe, S. Baird and J. Pedersen 2000 Rapid minipreparation of fungal DNA for PCR. J. Clin. Microbiol., 38: 471

The Korean Society of Plant Pathology 2009 List of Plant Diseases in Korea. $5^{\text {th }}$ edition. Suwon, The Korean Society of Plant Pathology, p. 853

Yun, H. Y., K. J. Lee, Y. H. Kim and S. K. Lee 2008 First report of Gymnosporangium globosum causing American hawthorn rust in Korea. Plant Pathol. J. 24: 84-86 